\title{
Validasi Konstruksi Faktor Model Spirituality and Spiritual Care Rating Scale Versi Bahasa Indonesia (SSCRS-BI) pada Mahasiswa Program Ners
}

\author{
Wastu Adi Mulyono \\ Jurusan Keperawatan Universitas Jenderal Soedirman
}

\section{Article Info}

Article History:

Diterima 30 November 2020

\section{Key words:}

Psikometrik; Religious;

Asuhan; Manajemen;

Kuesioner

\begin{abstract}
Pemenuhan kebutuhan spiritual pasien telah hampir ditinggalkan oleh perawat. Respon subjektif perawat terhadap isu spiritualtas dicurigai berkontribusi terhadap tidak adekuatnya asuhan spiritual. Oleh karena itu penelitian terhadap persepsi perawat terhadap isu spiritual ini perlu dikaji, sayangnya alat ukur untuk persepsi spiritual dan asuhan spiritual masih perlu kajian lebih dalam. Penelitian ini bertujuan untuk menguji apakah SSCRS BI sama atau berbeda dengan versi aslinya. Penelitian ini menggunakan pendekatan cross-sectional yang dilakukan untuk mengkaji persepsi 131 mahasiswa Program Ners yang sedang praktik profesi di beberapa rumah sakit di Jawa Tengah. Confirmatory Factor Analysis diaplikasikan untuk menguji struktur model SSCRS satu faktor dan dua faktor. Reliabilitas SSCRS Bahasa Indonesia juga diukur dari nilai koefisien Alpha Cronbach. Hasil penelitian menunjukkan Nilai CMNI/DF, CFI, TLI, RMSEA setiap model adalah sebagai berikut: Model 1 Original: 1,43; 0,875; 0,844; 0.875. Model 2, satu faktor 17 item: 2,225; 0,420; 0,38125;

0,097. Model 3, satu faktor 15 item: 1,924; 0,728, 0,683, 0,84. Model 4 dua faktor model 15 item: 0,$851 ; 0,753 ; 0,78 ; 0.081$. Struktur model dua faktor dengan 15 item terlihat lebih baik dibandingkan dengan yang 17 item (original). Meskipun demikian, Koefisien Alfa Cronbach masih di bawah nilai yang dapat diterima. Tapi MIC dapat diterima
\end{abstract}

\section{PENDAHULUAN}

Perawat perlu mempertimbangkan kembali persepsi mereka terhadap kebutuhan spiritual dalam memprioritaskan asuhan perawatan. Sebuah studi melaporkan keluhan pasien terhadap kurangnya dukungan perawat terhadap kebutuhan spiritual mereka selama dirawat di rumah sakit (Balboni et al., 2010). Kemungkinan kebutuhan ruhaniah bukan prioritas utamanya, karena perawat telah terbiasa menempatkan kebutuhan fisik pada urutan pertama mengikuti hirarki teori Maslow. Sementara kebutuhan spiritual diletakkan pada urutan terakhir, bagian puncak piramida. Oleh sebab itu, kebutuhan spiritual akan ditangani setelah urutan kebutuhan sebelumnya telah diatasi. Akibatnya, ketika beban kerja tinggi, perhatian perawat terhadap kebutuhan spiritual pasien akan longgar. Apalagi, sudah diketahui umum bahwa perawat di seluruh dunia telah menanggung beban kerja yang masif.

Corresponding author:

Wastu Adi Mulyono

wastu@unsoed.ac.id

Jurnal Kepemimpinan dan Manajemen Keperawatan, Vol 3 No 2, November 2020

DOI: http://dx.doi.org/10.26594/jkmk.v3.i2.557

e-ISSN 2621-5047 
Selain beban kerja, pendidikan yang tidak memadai memberikan kontribusi untuk dukungan yang tidak memadai bagi kebutuhan rohani pasien oleh para perawat (Ruder, 2013). Perawatan spiritual adalah menaruh pehatian relatif terhadap kebutuhan keagamaan dan eksistensial pasien, termasuk pertanyaan dan pengalaman mereka terhadap makna dan tujuan hidupnya (Jokhemsen in van Leeuwen, Tiesinga, Middel, Post, \& Jochemsen, 2009). Menurut definisi ini, seorang perawat harus mampu mengidentifikasi aspek keagamaan serta pertanyaan pasien tentang keberadaan danperan pasien dalam hidup mereka sendiri. Tidak kompeten dalam menilai isyarat kebutuhan rohani akan berakhir dengan kegagalan intervensi spiritual. Sementara, mengajarkan aspek spiritual dan keagamaan dalam pendidikan keperawatan atau dalam pelatihan berhadapan dengan pengaturan kerja yang menantang (Mulyono \& Chen, 2019). Belum lagi, tingkat pendidikan, masa kerja, pengalaman kerja, dan lingkup tempat bekerja juga menentukan persepsi para perawat tentang spiritualitas dan perawatan spiritual (Ozbasaran, Ergul, Temel, Aslan, \& Coban, 2011).

Banyak tantangan belajar perawatan spiritualitas. Penghalang berasal dari pengajar, siswa, dan lingkungan (Baldacchino, 2011). Siswa dan pengajar tidak puas dengan kajian spiritual rohani selama proses pembelajaran di sekolah (Boswell, Cannon \& Miller, 2013). Orang cenderung menghindari konfrontasi perspektif agama dalam pekerjaan atau diskusi karena menimbulkan polemik. Misalnya, kebijakan rumah sakit yang menyarankan bahwa penunggu pasien akan lebih baik memiliki jenis kelamin yang sama telah menjadi viral di media sosial dan menimbulkan perdebatan (Alfreda, 2019). Akibatnya, baik pengajar maupun siswa ragu untuk membahas secara terbuka.

Keraguan untuk mendiskusikan isu sensitif seperti agama atau spiritual dalam pendidikan dapat menghambat perkembangan pengetahuan. Meskipun kurikulum keperawatan sudah mencakup topik spiritual, kenyataannya, perspektif pribadi telah mencegah internalisasi konsep spiritualitas ke dalam memori perawat. Akibatnya, hanya sedikit perawat, -dalam studi sebelumnya-, mengingat topik yang sudah diajarkan selama pendidikan Mereka (Mulyono \& Chen, 2019). Kecanggungan antara nilai pribadi dan profesional perawat ini dapat menghambat proses transfer pengetahuan topik spiritual ini ke generasi perawat berikutnya (McSherry, \& Jamieson, 2013), seperti mahasiswa Ners.

Perawat pre-registered dalam penelitian ini adalah lulusan baru S1 Keperawatan yang menjalani magang klinis di rumah sakit dan komunitas sebelum mereka memasuki ujian kualifikasi sebagai perawat terdaftar. Di Indonesia itu disebut "program Ners". Program ini disediakan untuk 2-3 semester setelah lulus dari jenjang akademik (S1). Selama program ini mereka melakukan perawatan langsung dan juga mengorganisir perawatan di bawah pengawasan dari mentor atau instruktur klinis. Kompetensi yang diharapkan dari program ini adalah tingkat ketujuh KKNI. mampu mengelola sumber daya, memecahkan masalah, dan melakukan penelitian. Oleh karena itu, mengkaji perawat pre-registered ini akan bermanfaat untuk memprediksi perilaku mereka terhadap perawatan spiritual di masa depan.

\section{Spirituality and Spiritual Care Rating Scale}

Spirituality and Spiritual Care Rating Scale (SSCRS) dikembangkan tahun 1997 untuk populasi Inggris Raya. Tujuannya untuk mengidentifikasi persepsi perawat terhadap spiritualitas dan asuhan spiritual. Penulis asli menyusun skala dengan menganalisis tanggapan 559 perawat dengan beberapa dengan beberapa latar belakang pendidikan dan area spesialisasi. 
Sembilan area terkait dengan spiritualitas diidentifikasi: harapan, makna dan tujuan, pengampunan, keyakinan dan nilai, perawatan rohani, hubungan, kepercayaan pada Tuhan atau dewa, moralitas, dan kreativitas/ ekspresi diri (McSherry, Draper, \& Kendrick, 2002).

Instrumen orisinalnya terdiri dari 17 item dengan tipe skala Likert dan memiliki koefisien Alfa Cronbach 0,64. Skala ini mencakup 4 faktor (faktor $\mathrm{V}$ dihapus karena hanya memiliki satu item):-faktor ISpiritualitas (item F, H, I, J, L); -Faktor IIspiritual Care (item A, B, G, K, N); -Faktor IIIreligiusitas (item D, M, P);-faktor IVPersonalized Care (item N, O, Q). Versi bahasa Indonesia diterjemahkan dari versi aslinya pada tahun 2015. Koefisien keandalan dua set data dari dua studi sebelumnya di berbagai populasi perawat di Jawa Tengah dan Jawa Barat sangat baik (Mulyono \& Chen, 2019; Sutrinso, Swasti, \& Mulyono, 2019). Namun, kedua studi tersebut menggunakan SSCRS-BI sebagai satu faktor.

Penelitian ini bertujuan untuk menguji struktur dan faktor SSCRS pada perawat pra registrasi di Jawa Tengah, Indonesia.

\section{METODE}

\section{Prosedur penerjemahan dan adaptasi}

Prosedur penerjemahan dan adaptasi mengadopsi studi terjemahan sebelumnya dari SSCRS ke bahasa Portugis. Prosedurnya terdiri dari beberapa langkah seperti terjemahan, kesetaraan item, kembali terjemahan, kesetaraan semantik, penilaian panel, dan pengujian pretest, dan psikometri (Martins, Pinto, Caldeira, \& Pimentel, 2015; Streiner, Norman, \& Cairney, 2015). Dua pakar bahasa Inggris bersertifikat menerjemahkan versi bahasa Inggris untuk mendapatkan dua versi terjemahan SSCRS. Persamaan item dari SSCRS yang diterjemahkan tersebut dibahas dengan dua perawat dari laboratorium keperawatan dasar, Departemen/jurusan keperawatan, yang mengerti bahasa Inggris dan bahasa Indonesia dengan baik serta konsep spiritualitas dan asuhan spiritual dalam rangka merumuskan versi bahasa Indonesia. Beberapa perubahan dilakukan untuk mencocokkan dengan komunitas multikultural di Indonesia. Kata gereja diterjemahkan ke dalam "tempat ibadat" bukan "Gereja" yang hanya mewakili Kristen, pendeta diterjemahkan ke dalam "tokoh agama" bukannya "Katalog" yang hanya mewakili Kristen atau "ulama" untuk Muslim.

Tabel 1

Items in SSCRS-BI

Lingkari satu jawaban yang paling mewakili seberapa besar Anda setuju dengan setiap pernyataan berikut

STS=Sangat tidak setuju TS= Tidak Setuju N=Netral S=Setuju SS=Sangat Setuju

\section{Items}

a) Saya percaya perawat mampu memberikan perawatan spiritual dengan mengadakan kunjungan oleh pihak rumah sakit atau pemuka agama dari pihak pasien sendiri jika diminta.

b) Saya percaya perawat mampu memberikan perawatan spiritual dengan menunjukkan kebaikan, kepedulian dan keramahan dalam memberikan perawatan.

c) Saya percaya spiritualitas berkaitan dengan kebutuhan untuk memaafkan dan dimaafkan.

d) Saya percaya spiritualitas hanya berkaitan dengan pergi ke masjid/gereja/tempat ibadah.*)

e) Saya percaya spiritualitas tidak berkaitan dengan kepercayaan atau keimanan kepada Tuhan atau Yang Maha Agung.*)

f) Saya percaya spiritualitas adalah tentang pencarian makna hal-hal baik atau buruk yang terjadi dalam hidup.

g) Saya percaya perawat dapat memberikan perawatan spiritual dengan menghabiskan waktu dengan pasien melalui pemberian dukungan dan penentraman khususnya pada saat dibutuhkan.

h) Saya percaya perawat dapat memberikan perawatan spiritual dengan membatu pasein menemukan makna dan tujuan penyakitnya.

i) Saya percaya spiritualitas itu tentang memiliki harapan dalam hidup.

j) Saya percaya spiritualitas itu berkaitan dengan cara seseorang menjalani hidupnya saat ini.

k) Saya percaya dapat memberikan perawatan spiritual dengan mendengarkan dan menyediakan waktu untuk pasien yang ingin 
membicarakan dan mengetahui ketakutan, kecemasan dan kesulitan mereka.

l) Saya percaya spiritualitas adalah paduan kekuatan yang memungkinkan seseorang merasa damai dan nyaman dengan hidupnya dan dunianya.

m) Saya percaya spiritualitas tidak berkaitan dengan seni, kreativitas dan ekspresi diri.*)

n) Saya percaya perawat dapat memberikan perawatan spiritual dengan cara menghormati privasi, harga diri, religiusitas dan kepercayaan budaya pasien.

o) Saya percaya spiritualitas berkaitan dengan persahabatan dan hubungan personal.

p) Saya percaya spiritualitas tidak dapat diterapkan terhadap seorang atheis atau agnostik.*)

q) Saya percaya spiritualitas termasuk moral manusia.

Catatan $^{*}$ ) unfavourable items

Versi pertama SSCRS bahasa Indonesia (SSCRS-BI) dilanjutkan dengan langkah penerjemahan kembali. Seorang perawat bersertifikat dengan kemampuan bahasa Inggris tinggi dan pernah tinggal di Inggris diminta untuk terjemah ulang SSCRS ke dalam bahasa asli (Inggris). Kemudian, versi diterjemahkan kembali dan versi asli dibandingkan dalam istilah idiomatik dan semantik kesetaraan dengan hakim panel. Hakim panel terdiri dari dua perawat, peneliti sendiri, dan guru bahasa Inggris. Kemudian, para hakim ini dibahas bersamasama untuk membuat konsensus untuk membangun versi pra-final SSCRS-BI.

Sebuah cognitive interview dilakukan untuk pre-test SSCRS-BI. Sepuluh mahasiswa sarjana di Universitas Jenderal Soedirman diminta untuk mengisi kuesioner. Setelah itu, setiap siswa diwawancarai Apakah mereka menemukan kesulitan atau salah paham pertanyaannya. Langkah ini selesai tanpa revisi besar. Akhirnya, SSCRS-BI siap untuk pengujian psikometri.

\section{Desain dan sampel penelitian}

Penelitian rancangan cross-sectional dilakukan untuk menguji SSCRS-BI pada mahasiswa Ners yang menjalani magang klinis di rumah sakit di Provinsi Jawa
Tengah, Indonesia. Kriteria kelayakan untuk pengambilan sampel termasuk siswa yang sudah diterima di "program Ners" di Universitas, dan setidaknya telah bergabung dalam program magang di rumah sakit selama satu bulan.

Seratus tujuh puluh (170) mahasiswa diharapkan untuk berpartisipasi dalam studi berdasarkan aturan praktis; satu item sepuluh responden. Teknik convenience sampling diterapkan untuk merekrut sampel. Kegiatan pengumpulan data dimulai pada awal September 2016. Proses pengumpulan data dihentikan pada akhir 2016 Desember setelah diperpanjang satu bulan. Keterbatasan asisten penelitian terlatih untuk mencakup seluruh wilayah di Jawa Tengah selama batas waktu tiga bulan, serta kurangnya pendanaan, menjadi penghalang utama tercapainya jumlah sampel, karena meningkatnya biaya tidak dapat diatasi. Namun, 131 sampel dianggap memada untuk pengujian statistik.

\section{Analisis data}

SPSS versi 21 digunakan untuk analisis deskriptif data mentah serta perbedaan intra-sampel, urutan pertama dan korelasi parsial serta analisis faktor eksplorasi. Struktur faktorial dari SSCRS-BI diinves-tigasi dengan cara pemodelan persamaan struktural (SEM), memanfaatkan kemung-kinan maksimum. CFA dilakukan untuk membandingkan struktur faktor versi asli dan versi bahasa Indonesia.

Model fit dari model SEM menggunakan rasio nilai Chi-Square untuk derajat kebebasan (CMINI/DF), Comparative Fit Indeks (CFI), Tucker-Lewis-index (TLI) dan Root Mean Square Estimation (RMSEA) (Kline, 2005). Dalam rangka untuk menilai kesesuaian model diterapkan konvensional cut-off kriteria (Kecocokan Baik: CMINI/ DF $<2$; CFI $>0,97$; TLI $>0,97$, RMSEA $<0,10$; layak diterima: CMINI/ DF <3; CFI >0,95; TLI: > $0,95$, RMSEA $<0,05)$. Selanjutnya keandalan ditentukan koefisien Alpha Cronbach's lebih 
tinggi dari 0,7 dan berarti korelasi antar item yang lebih tinggi dari 0,25 dianggap sebagai cukup (Streiner, Norman, \& Cairney, 2015; Tiesinga, Middel, Post, Jochemsen, \& Van Leeuwen, 2009).

\section{HASIL}

\section{Karakteristik Responden}

Rerata usia responden adalah 22,58 $( \pm 0,61)$. Sebagian besar responden adalah perempuan 81 (61,8\%). Proporsi ini umum bagi penduduk perawat di Indonesia. Serupa dengan gender, Islam mendominasi afiliasi keagamaan responden (96,9\%).

Tabel 2

Karakteristik responden ( $\mathrm{n}=131)$

\begin{tabular}{|c|c|c|}
\hline Indikator & $\mathrm{f}$ & $\%$ \\
\hline $\begin{array}{l}\text { Usia } \\
\qquad \text { Mean }=22,58 \\
\text { SD }=0,61 \\
\text { Jenis Kelamin }\end{array}$ & & \\
\hline Perempuan & 81 & 61,8 \\
\hline Laki-laki & 50 & 38,2 \\
\hline \multicolumn{3}{|l|}{ Agama } \\
\hline Islam & 127 & 96,9 \\
\hline Protestan & 4 & 3,1 \\
\hline \multicolumn{3}{|l|}{ Lokasi Praktik } \\
\hline $\begin{array}{l}\text { Jawa Tengah bagian Selatan } \\
\text { (Cilacap, Banyumas, Kebumen) }\end{array}$ & 97 & 74,0 \\
\hline $\begin{array}{ll}\text { Jawa Tengah } & \text { Sentral } \\
\text { (Purbalingga, } & \text { Wonosobo, } \\
\text { Temanggung, } & \text { Wonosobo, } \\
\text { Boyolali, Surakarta) }\end{array}$ & 27 & 20,6 \\
\hline $\begin{array}{l}\text { Daerah Pantura (Pemalang, } \\
\text { Pekalongan, Semarang, Tegal) }\end{array}$ & 7 & 5,3 \\
\hline \multicolumn{3}{|c|}{$\begin{array}{l}\text { Berhadapan dengan pasien dengan kebutuhan } \\
\text { Spiritual Ketika Praktik }\end{array}$} \\
\hline No & 18 & 13,7 \\
\hline Yes & 113 & 86,3 \\
\hline
\end{tabular}

Tabel 3

Rerata dan Median Skor

\begin{tabular}{ll}
\hline Indikator & skor \\
& \\
\hline $\mathrm{N}$ & 131 \\
Mean & 67.91 \\
Std. Deviation & 5,01 \\
Median & 68.00 \\
Range (theoretical) & $57-82(17-85)$ \\
Skewness & 0.372 \\
Kurtosis & 0.323
\end{tabular}

Goodness of fits:

chi square: 120,099

probability:, 006

degree of freedom: 84

GFI: :,888
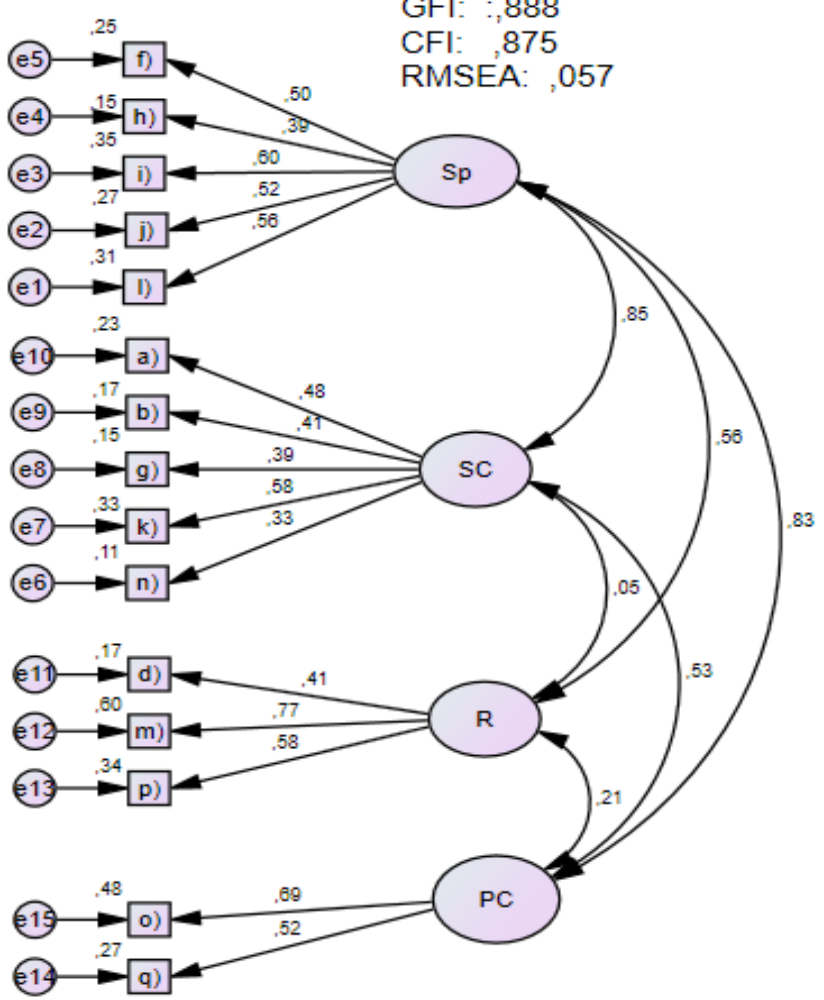

Gambar 1.

Model 1, Four Factors Construct (original)

\section{Skor SSCRS}

Skor median SSCRS 68 dengan skala berkisar dari 57-82; kisaran teoritis SSCRS adalah 17- 85; Mean 67,91 (SD 5,01). Dibandingkan dengan skor di kisaran median 0-100 ini dan berarti sama dengan 75 dan 74,86 . 


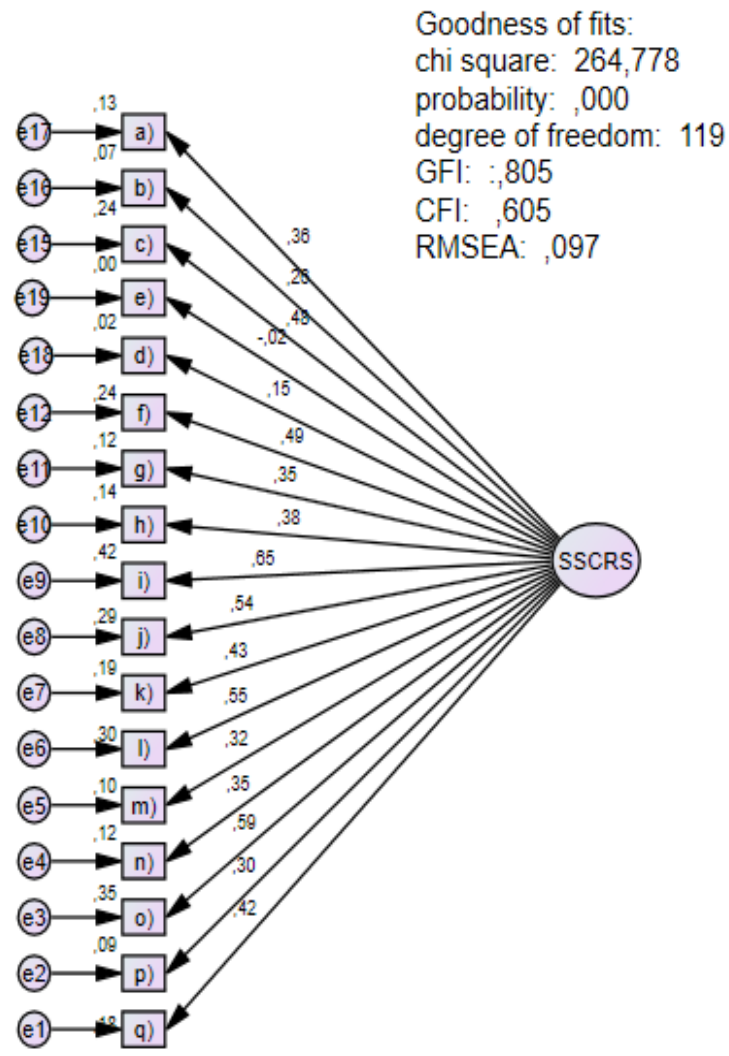

Gambar 2.

Model 2: Single Factor Construct

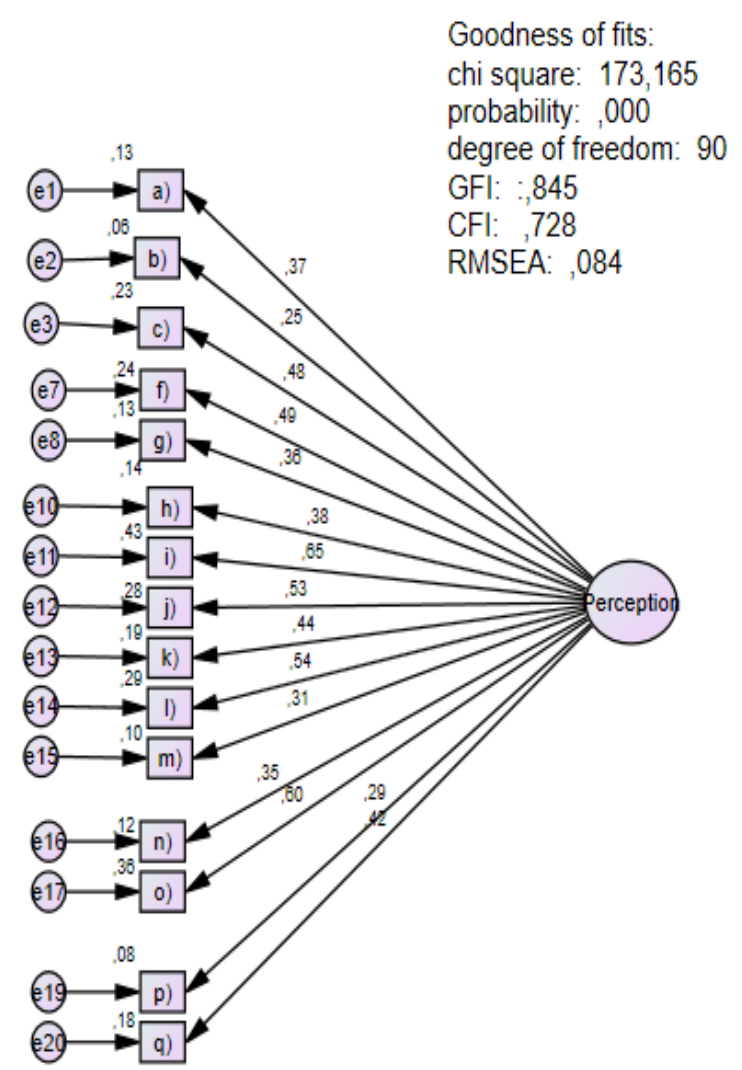

Gambar 3

Single Factor Construct (15 items)

\section{Komponen faktor dalam studi dibandingkan dengan asli}

Faktor I-Spiritualitas (item F, H, I, J, L); Faktor II-spiritual Care (item A, B, G, K, N); Faktor III-religiusitas (item D, M, P); -Faktor IV-Personalized Care (item N, O, Q).

Karena variabel $n$ dalam struktur asli diletakkan pada faktor II dan faktor IV, CFA tidak bisa melanjutkan analisis. Oleh karena itu, variabel $n$ dalam perawatan pribadi telah dihapus

Awalnya, empat faktor model struktur diuji. Alfa Cronbach adalah 0.62 (miic 4,11), 0.51 ( miic 4,08), dan 0,60 (miic 3.6), 5,11 miic $(4,06)$. Struktur ini tampak tidak dapat diterima, karena Alfa lebih rendah dari 0,7. Oleh karena itu, SSCRS BI sebagai satu struktur faktor diuji,

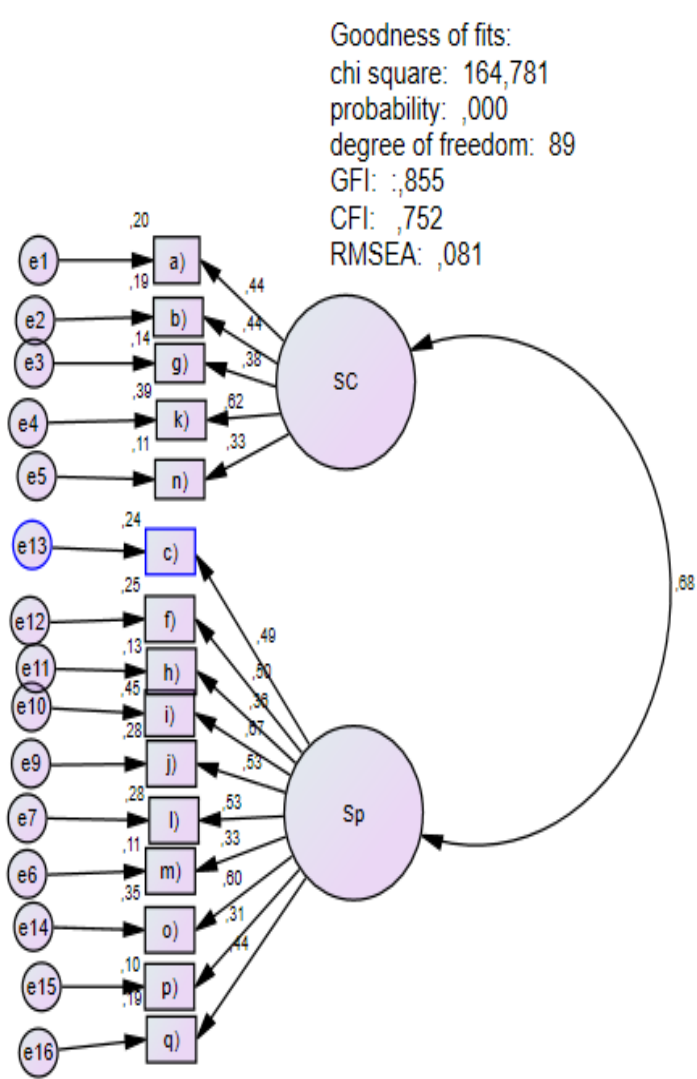

Gambar 4 .

Model 4: Two Factor Construct (15 items) 
Alfa Cronbach koefisien 0,71 (MIIC 3,99), tetapi dua variabel $(d, e)$ memiliki koefisien rendah atau negatif yang disarankan untuk menghapus. Setelah menghilangkan variabel d dan e, strukturnya dievaluasi ulang. Faktor tunggal dengan 15 item terbentuk. Koefisien Alfa meningkat menjadi 0,75 (MIIC 4,0). Struktur faktor hasil ini dapat diterima.

Karena dalam studi sebelumnya, variabel $a$, $b, g, k$, dan $n$ selalu bersama-sama berkumpul dalam satu faktor, mereka dikelompokkan dalam satu faktor yaitu perawatan rohani, maka yang lain dikelompokkan menjadi satu faktor yang disebut spiritualitas.

Struktur baru terdiri dari dua faktor. Faktor pertama yang disebut spiritualitas yang terdiri dari $c, f . h, i, j, l, m, o, p$, dan $q$. Keandalan dari faktor ini adalah Apfa Cronbach 0,731 (MIIC 3,97), namun faktor perawatan spiritual 0,513 (MIIC: 0,41).

Tabel 4

Model Factor Fit

\begin{tabular}{lrlcrlllll}
\hline Consturct Model & CMNI/DF & & CFI & & \multicolumn{2}{l}{ TLI } & & \multicolumn{2}{l}{ RMSEA } \\
\hline Model 1 Original & 1,430 & good & 0,875 & NA & 0,844 & NA & 0,875 & NA \\
Model 2 single factor 17 items & 2,225 & acceptable & 0,420 & NA & 0,381 & NA & 0,097 & good \\
Model 3, single Factor 15 items & 1,924 & good & 0,728 & NA & 0,683 & NA & 0,840 & NA \\
$\begin{array}{l}\text { Model 4 two factor model 15 } \\
\text { items }\end{array}$ & 1,851 & good & 0,753 & NA & 0,780 & NA & & 0,081 & good \\
\hline
\end{tabular}

\section{PEMBAHASAN}

SSCRS BI gagal untuk memenuhi empat faktor model terstruktur. Karena koefisien keandalan lebih rendah dari titik potong yang diterima (Alpha 0,7 dan MIIC 0,2). Namun, bila dibandingkan dengan koefisien asli mereka yang relatif mirip (McSherry et al., 2002) . Hasil ini relatif mirip dengan versi Portugis. Mereka melaporkan koefisien Alfa Cronbach dari masing-masing faktor adalah 0,66, 0,69, 0,64 dan 0,59. Sebagai faktor tunggal, koefisien reliabilitas SSCRS meningkat menjadi 0,76 (Martins et al., 2015) .

Penelitian ini mendukung kami sebelumnya diuji pada 248 perawat di Jawa Barat, kehandalan adalah 0,75 , miic 0,29 (sutrinso et al., 2019) . Namun, studi ini dianggap sebagai alat konstruksi faktor tunggal. Kajian ini juga mengidentifikasi fakta bahwa barang yang menanyakan aspek keagamaan (d dan e) tidak sah. Item ini adalah pertanyaan negatif, mungkin responden tidak memperhatikan mereka.
Ketika faktor itu dikategorikan sebagai dua konsep, spiritualitas dan perawatan spiritual, faktor pertama yang mewakili konsep spiritualitas melampaui ambang batas yang ditettapkan. Namun faktor yang mewakili asuhan spiritual (spiritual care) gagal. Nampaknya konsep asuhan spiritualitas agak sulit dipahami daripada konsep spiritualitas. Mengajarkan konsep spiritualitas sama sulitnya dengan asuhan spiritual. Para mahasiswa Ners ini tidak memperoleh contoh dan model di tatanan praktis. Kurangnya dokumentasi mungkin berkontribusi (Mulyono \& Chen, 2019).

\section{SIMPULAN}

Model dua-faktor dengan 15 item diidentifikasi lebih baik daripada versi asli. Namun, Koefisien Alfa Cronbach berada di bawah ambang batas yang dapat diterima untuk faktor perawatan spiritual meskipun MIIC dapat diterima. 


\section{UCAPAN TERIMAKASIH}

Kami ingin berterima kasih kepada Chandra, Arif, Yudi dan lain-lain sahabat yang membantu saya dalam mengumpulkan data.

\section{REFERENSI}

Alfreda, E. (2019, 11 Juni 2019). Viral rsud kota tangerang larang pasien ditunggu dan diantar yang bukan mahramnya, ini respon dinkes. Tribunjakarta.com. Retrieved from https://jakarta.tribunnews.com/2019/06/ 11 viral-rsud-kota-tangerang-larangpasien-ditunggu-dan-diantar-yang-bukanmahramnya-ini-respon-dinkes.

Baldacchino, D. R. (2011). Teaching on spiritual care: the perceived impact on qualified nurses. Nurse Education in Practice, 11(1), 47-53. doi:10.1016/j.nepr.2010.06.008

McSherry, W., Draper, P., \& Kendrick, D. (2002). The construct validity of a rating scale designed to assess spirituality and spiritual care. International Journal of Nursing Studies, 39(7), 723-734. doi:10.1016/S00207489(02)00014-7

Mulyono, W. A., \& Chen, C.-H. (2019). Nurses' perceptions of spirituality and spiritual care and the challenges of learning spirituality. Jurnal Keperawatan Soedirman, 14(2).
Ozbasaran, F., Ergul, S., Temel, A. B., Aslan, G. G., \& Coban, A. (2011). Turkish nurses' perceptions of spirituality and spiritual care. Journal of Clinical Nursing, 20(21-22), 31023110. doi:10.1111/j.13652702.2011.03778.x

Ruder, S. (2013). Spirituality in nursing: nurses' perceptions about providing spiritual care. Home Healthcare Nurse, 31(7), 356-367. doi:10.1097/NHH.0b013e3182976135

Streiner, D. L., Norman, G. R., \& Cairney, J. (2015). Health measurement scales: a practical guide to their development and use: Oxford University Press, USA.

Sutrinso, N., Swasti, K. G., \& Mulyono, W. A. (2019). Pengetahuan, persepsi dan sikap perawat rsud arjawinangun tentang asuhan keperawatan spiritual. Jounal of Bionursing, 1(1), 22-33.

Tiesinga, L. J., Middel, B., Post, D., Jochemsen, H., \& Van Leeuwen, R. (2009). The validity and reliability of an instrument to assess nursing competencies in spiritual care. Journal of Clinical Nursing, 18(20), 2857-2869. doi:10.1111/j.1365-2702.2008.02594.x

van Leeuwen, R., Tiesinga, L. J., Middel, B., Post, D., \& Jochemsen, H. (2009). The validity and reliability of an instrument to assess nursing competencies in spiritual care. Journal of Clinical Nursing, 18(20), 2857-2869. doi:10.1111/j.1365-2702.2008.02594.x 